\title{
Genetic relationships between detailed reproductive traits and performance traits in Holstein-Friesian dairy cattle
}

\author{
T. R. Carthy, ${ }^{*} †$ D. P. Ryan, $\ddagger$ A. M. Fitzgerald, ${ }^{*}$ R. D. Evans, $\S$ and D. P. Berry ${ }^{* 1}$ \\ *Animal and Grassland Research and Innovation Centre, Teagasc, Moorepark, Co. Cork, Ireland \\ †School of Veterinary Medicine, University College Dublin, Belfield, Dublin, Ireland \\ $\ddagger$ Reprodoc Ltd., Fermoy, Co. Cork, Ireland \\ §Irish Cattle Breeding Federation, Bandon, Co. Cork, Ireland
}

\begin{abstract}
The objective of the study was to estimate the genetic relationships between detailed reproductive traits derived from ultrasound examination of the reproductive tract and a range of performance traits in HolsteinFriesian dairy cows. The performance traits investigated included calving performance, milk production, somatic cell score (i.e., logarithm transformation of somatic cell count), carcass traits, and body-related linear type traits. Detailed reproductive traits included (1) resumed cyclicity at the time of examination, (2) multiple ovulations, (3) early ovulation, (4) heat detection, (5) ovarian cystic structures, (6) embryo loss, and (7) uterine score, measured on a 1 (little or no fluid with normal tone) to 4 (large quantity of fluid with a flaccid tone) scale, based on the tone of the uterine wall and the quantity of fluid present in the uterus. (Co) variance components were estimated using a repeatability animal linear mixed model. Genetic merit for greater milk, fat, and protein yield was associated with a reduced ability to resume cyclicity postpartum (genetic correlations ranged from -0.25 to -0.15 ). Higher genetic merit for milk yield was also associated with a greater genetic susceptibility to multiple ovulations. Genetic predisposition to elevated somatic cell score was associated with a decreased likelihood of cyclicity postpartum (genetic correlation of -0.32) and a greater risk of both multiple ovulations (genetic correlation of 0.25 ) and embryo loss (genetic correlation of 0.32). Greater body condition score was genetically associated with an increased likelihood of resumption of cyclicity postpartum (genetic correlation of 0.52 ). Genetically heavier, fatter carcasses with better conformation were also associated with an increased likelihood of resumed cyclicity by the time of examination (genetic correlations ranged from 0.24 to 0.41 ). Genetically heavier carcasses were associated with an inferior uterine score as well
\end{abstract}

Received May 18, 2015.

Accepted October 15, 2015.

${ }^{1}$ Corresponding author: Donagh.Berry@teagasc.ie as a greater predisposition to embryo loss. Despite the overall antagonistic relationship between reproductive performance and both milk and carcass traits, not all detailed aspects of reproduction performance exhibited an antagonistic relationship.

Key words: fertility, milk production, body size, calving, carcass

\section{INTRODUCTION}

Historical intensive selection for milk production in dairy cows has succeeded in increasing milk yield, but has done so to the detriment of functional traits such as animal health (Berry et al., 2011a) and reproductive performance (Veerkamp and Beerda, 2007; Berry et al., 2014). Reproductive traits are now routinely included in national breeding goals to improve reproductive performance while still achieving genetic gain for milk production (Miglior et al., 2005). Reproductive traits included in dairy cow breeding objectives, however, have almost exclusively been limited to producerrecorded traits such as calving interval or days open. Detailed reproductive traits, including the ability of the cow to resume and express estrus postpartum, establish and maintain pregnancy, as well as cow uterine health, can provide a greater insight into reproductive performance. Detailed reproductive traits, measured by hormone levels (Royal et al., 2002a; Berry et al., 2012) and ultrasound examination of the reproductive tract (Carthy et al., 2015), have been shown to be genetically associated with traditional reproductive traits. Little is known, however, about the effect of current breeding strategies on the detailed aspects of reproductive performance such as follicular dynamics and uterine health.

Extensive studies have documented the antagonistic genetic relationship between milk production and traditional reproductive traits (Berry et al., 2014). Greater milk production has been associated with a reduction in cyclicity postpartum (Royal et al., 2002b; Fitzgerald et al., 2014b) and an increased likelihood of both cystic structures (Hooijer et al., 2001; Zwald et al., 
2004; Fitzgerald et al., 2014b) and multiple ovulation (Fitzgerald et al., 2014b). Although generally confined to traditional reproductive traits, the genetic correlations between reproductive performance and other performance traits (e.g., type traits, BCS, live weight) have also been documented in several populations (Berry et al., 2014). Inferior genetic merit for calving interval has been reported to exist in dairy cows genetically predisposed to a greater risk of calving difficulty (Eaglen et al., 2013). Corresponding genetic associations with detailed aspects of reproductive performance in lactating dairy cows are, however, lacking.

The objective of the present study was to estimate the genetic relationships between detailed reproductive traits, derived from ultrasound examination of the reproductive tract, and a range of performance traits in Holstein-Friesian dairy cows. Performance traits considered included calving performance (i.e., calving difficulty and perinatal mortality), milk production, carcass related traits, BCS, and body size. The results of this study will fill a knowledge gap on the genetic parameters necessary to quantify the implications of current breeding strategies on the underlying, more detailed components of reproductive performance.

\section{MATERIALS AND METHODS}

\section{Data}

Records were available from the Irish Cattle Breeding Federation (Bandon, Co. Cork, Ireland) database on (1) ultrasound examination records of the reproductive tract, (2) calving performance, (3) individual cow milk production, (4) carcass traits, and (5) linear type traits. Supplementary data on animal pedigree, breed composition, and cow parity were also available.

Detailed Reproductive Traits. Detailed reproductive traits were derived from ultrasound examination of the reproductive tract carried out by one commercial company (Reprodoc Ltd., Fermoy, Co. Cork, Ireland) using real-time B-mode ultrasound scanner with a $5-\mathrm{MHz}$ transducer. Ultrasound examinations were performed at various time points postpartum at the discretion of the producer. Data were available on 194,880 ultrasound records from 114,306 lactations on 72,120 dairy cows in 894 herds. The traits have been described in detail by both Carthy et al. (2014) and Fitzgerald et al. (2014a). The detailed reproductive traits included (1) the resumption of cyclicity (CYC), (2) multiple ovulation (MO), (3) early ovulations (EO), (4) detected heat (DH), (5) cystic structures (CS), (6) embryo loss (EL), and (7) uterine score (USC).

Resumption of cyclicity was defined as having resumed normal estrus cyclicity at the time of examination and was defined in this study as the presence $(\mathrm{CYC}=1)$ or the absence $(\mathrm{CYC}=0)$ of a noncystic corpus luteum (CL) on the ovaries at the time of examination (Carthy et al., 2014). Multiple ovulations were defined as the presence of $>1$ CL $(\mathrm{MO}=1)$ on one or both ovaries at the time of examination in cycling cows (Fitzgerald et al., 2014a). Early ovulation was defined as ovulation having occurred $(\mathrm{EO}=1)$ or not $(\mathrm{EO}=0)$ by $15 \mathrm{~d}$ postpartum. Date of ovulation was determined by the size and density of the CL up to $6 \mathrm{~d}$ postovulation, after which an accurate ovulation date could not be determined. Therefore, EO could only be determined from ultrasound examinations up to $21 \mathrm{~d}$ postpartum; if examination occurred $>21 \mathrm{~d}$ postpartum EO was set to missing.

Detected heat was only defined within a herd's AI breeding season; if no ovulation was detected by ultrasound examination during this period, $\mathrm{DH}$ was set to missing. If an insemination occurred within $5 \mathrm{~d}$ of the estimated date of ovulation, determined by ultrasound examination, then heat was assumed to have been detected $(\mathrm{DH}=1)$. If no recorded insemination existed within $\pm 5 \mathrm{~d}$ from the date of ovulation, heat was assumed not to have been detected $(\mathrm{DH}=0)$.

Cystic structures were defined as the presence (CS $=1)$ or absence $(\mathrm{CS}=0)$ of a cystic structure $(>25$ $\mathrm{mm}$; follicular or luteal) on the ovaries at time of ultrasound examination (Carthy et al., 2014). Uterine score, measured on a scale from 1 to 4 , was based on the tone of the uterine wall, the size of the lumen, and the quantity of fluid present in the uterus (Carthy et al., 2014). Uterine score was defined as (1) little or no fluid $(<2 \mathrm{~mm})$ with normal tone and normal lumen, (2) small quantity of fluid $(2-5 \mathrm{~mm})$ with normal tone and slightly enlarged lumen, (3) large quantity of fluid $(5-60 \mathrm{~mm})$ with moderately flaccid tone and enlarged lumen, and (4) very large quantity of fluid (>60 mm) with a flaccid tone and very enlarged lumen.

Embryo/fetal loss was assumed to have occurred if an embryo was deemed to be unviable (i.e., no detectable heartbeat) at the time of ultrasound examination $(\mathrm{EL}=1)$. However, if a subsequent calving date was less than $260 \mathrm{~d}$ from date of examination $(<3 \%$ of recorded unviable embryos), embryo loss was assumed not to have occurred $(\mathrm{EL}=0)$. Predicted calving date was calculated from the estimated gestational age of embryo/fetus at the time of examination, assuming $283 \mathrm{~d}$ gestation length (i.e., average gestation length of different dairy breeds; Norman et al., 2009). If a cow was determined pregnant at ultrasound examination and the subsequent calving date was greater than 30 $\mathrm{d}$ after predicted calving date then embryo/fetal loss was assumed to have occurred $(\mathrm{EL}=1)$. If subsequent calving date was less than $30 \mathrm{~d}$ after estimated calving 
date then embryo/fetal loss was assumed not to have occurred $(E L=0)$. With the exception of an embryo determined unviable at ultrasound examination, if subsequent calving dates for a pregnancy diagnosis were not yet available (i.e., calving date is in the future) then EL was set to missing.

Consistent with the national evaluations, data from cows with a calving interval $<300$ or $>600 \mathrm{~d}$ were discarded (Berry et al., 2013). If no record of a subsequent calving date existed, records of cows calved $>600 \mathrm{~d}$ by the time of ultrasound examination and identified as nonpregnant were discarded. After ultrasound examination, treatment may have been recommended for a selection of the reproductive tract classifications; however, no knowledge was available on whether or not any treatment subsequently occurred. Therefore, any ultrasound examinations for the remainder of that cow's lactation were discarded, with the exception of a pregnant diagnosis. Only herds that had greater than $80 \%$ of their cows examined in a calendar year were retained. Only Holstein-Friesian cows were retained for inclusion in the present study because of a paucity of records from other dairy breeds. Contemporary groups of herd-year-season of calving were defined based on an algorithm described in detail by Berry and Evans (2014). Within a given herd, the algorithm groups animals together that calve around the same period. Contemporary groups were defined for each detailed reproductive trait separately. Herd-year-seasons that contained less than 5 animals were removed from the analysis.

Calving Performance Traits. Data were available on $5,872,465$ calving events from $2,218,544$ dairy cows in 19,637 herds between the years 2008 and 2013. In Ireland, calving difficulty is a producer-recorded trait scored on a 4-point scale: (1) no assistance, (2) some assistance (assistance by one person), (3) considerable assistance (assistance by more than one person or assistance with calf puller), and (4) veterinary assistance (including cesarean). Stillbirth is also producer-recorded and was defined as whether or not a calf was dead or died within $24 \mathrm{~h}$ of calving; it is a legal requirement to record animal mortality in Ireland. Parities $>10$ were discarded and parities $>5$ were grouped together as parity $5+$. Only calving records with a known sire of both the calf and the Holstein-Friesian dam were retained. Contemporary groups of herd-year-season of calving were defined for both dystocia and perinatal mortality separately using the algorithm described previously; contemporary groups containing fewer than 5 records were discarded.

Milk Production Traits. Data were available on 2,787,918 individual cow 305-d milk, fat, and protein lactation yields from 1,169,354 cows in 11,618 herds between the years 2008 and 2013. Milk fat concentration, protein concentration, and fat-to-protein ratio were calculated. Somatic cell count was normalized to SCS by taking the natural logarithm of lactation geometric mean somatic cell count. Milk, fat, or protein yield records greater than 4 standard deviations from the mean were discarded. Only lactation lengths between 100 and $400 \mathrm{~d}$ from Holstein-Friesian cows with a known sire were retained. Parities $>10$ were discarded and parities $>5$ were grouped together as parity $5+$. Contemporary groups of herd-year-season of calving were defined based on an previously described algorithm. Records from contemporary groups with less than 5 animals were discarded.

Carcass Traits. Data were available on carcass fat, carcass conformation, and carcass weight from 4,162,212 animals born in 96,857 dairy herds between the years 2007 and 2014. Carcass data are collected on the progeny of Holstein-Friesian cows as well as on cows themselves when culled. Carcass weight was measured approximately $2 \mathrm{~h}$ after slaughter after the removal of the head, legs, thoracic and abdominal organs, internal fats, and hide. Carcass conformation and carcass fat grade were scored using the EUROP classification system (where $\mathrm{E}=$ excellent, $\mathrm{U}=$ very good, $\mathrm{R}=$ good, $\mathrm{O}$ $=$ fair, and $\mathrm{P}=$ poor ; the EUROP classification grades were transformed to a 15-point linear scale, as outlined by Hickey et al. (2007). Cows were defined as females that calved at least once; only cows greater than 15 mo of age and less than 240 mo of age were retained. For all other animals (i.e., females who never calved or males), only Holstein-Friesian animals greater than 10 mo and less than 41 mo old with carcass weights between 150 and $550 \mathrm{~kg}$ were retained. Contemporary groups were defined separately for cows and all other cattle, thereby treating progeny carcass traits separately from cow carcass traits. Contemporary groups of herd-year-season of slaughter for cow carcass records and herd-year-season of slaughter by sex for progeny carcass records were defined using the algorithm previously described; only contemporary groups containing greater than 5 records were retained.

Linear Type Traits. Linear type traits are a subjective assessment of the physical characteristic of cows measured on a scale of 1 to 9. Linear type traits scored in Ireland include body-related traits, udder-related traits, feet-related traits, and other traits; only bodyrelated traits were considered in the present study. Data were available on 180,035 linear type traits assessments from primiparous Holstein-Friesian dairy cows in 4,835 herds between the years 2004 and 2014. Only the first classification record per cow, undertaken within 
the first $305 \mathrm{~d}$ of lactation, was retained. Each trait was adjusted within classifier by year of inspection to a common variance. Only cows with a known sire were considered in the analysis. Contemporary groups of herd-year-season of classification were defined using the algorithm previously described; contemporary groups containing less than 5 records were discarded.

\section{Data Analysis}

For computational reasons, a random sample of herds for the performance traits was taken; no such sampling was applied to the detailed reproductive traits. The final number of records per trait is in Table 1 (detailed reproductive traits and calving performance) and 2 (milk production, carcass traits and linear type traits). The pedigree of each animal was traced back at least 4 generations (where available); the number of animals in the pedigree depended on the traits included in the analysis; for the detailed reproductive traits the pedigree included 133,280 animals. Coefficients of heterosis and recombination loss for each animal was calculated as $1-\sum_{i-1}^{2} \operatorname{sire}_{i} \cdot d a m_{i}$, and $1-\sum_{i-1}^{2} \frac{\operatorname{sire}_{i}^{2}+d a m_{i}^{2}}{2}$, respectively, where sire $_{i}$ and $d a m_{i}$ are the proportion of breed $i$ (across the 2 breeds Holstein and Friesian) in the sire and dam, respectively (VanRaden and Sanders, 2003).

Variance components were estimated by restricted maximum likelihood in ASREML (Gilmour et al., 2009) using an animal linear mixed model with the exception of the calving performance traits where a sire-maternal grandsire model was used. Genetic correlations between traits were estimated using a series of bivariate animal linear mixed models. The following models for the detailed reproductive traits were used:

$$
\begin{aligned}
P= & \mu+\text { parity }+ \text { HYS }+ \text { stage }+ \text { Het }+ \text { Rec } \\
& +\sum_{i=1}^{2} \text { Breed }_{i}+{\text { animal }+p e_{a}+p e_{w}+e,}_{Q=} \mu+\text { parity }+ \text { HYS }+ \text { Het }+ \text { Rec }^{2} \text { Breed }_{i}+\text { animal }^{2} \text { pe }_{a}+p e_{w}+e,
\end{aligned}
$$

where $P$ is the observed trait of CYC, CS, MO, DH, and USC (i.e., multiple measures during lactation), and $Q$ is the observed trait of $E L$ and $E O, \mu$ is the mean of trait, parity is the fixed effect of parity $(1,2,3,4$, or $5+), H Y S$ is the fixed effect of contemporary group, stage is the fixed effect stage of lactation at time of examination ( 0 to 14,15 to 39,40 to 84,85 to 149,150 to 300 , and $>300 \mathrm{~d}$ postcalving), Het is the fixed effect of the coefficient of heterosis, Rec is the fixed effect of the coefficient of recombination loss, $\sum_{i=1}^{2}$ Breed $_{i}$ is proportion of each breed $(i=$ Holstein and Friesian), animal is the random genetic effect, $p e_{a}$ is the random permanent environment effect across lactations, $p e_{w}$ is the random permanent environment effect within lactation, and $e$ is the random residual effect.

Models used for the performance traits were

$$
\begin{aligned}
Y= & \mu+\text { parity }_{d a m}+\text { sex }_{\text {calf }}+H Y S+\text { Het }_{d a m} \\
& + \text { Rec }_{d a m}+\sum_{i=1}^{2} \text { Breed }_{i}+\text { sire }+ \text { mgs }+ \text { pe } e_{d a m}+e,
\end{aligned}
$$

Table 1. Number of records $(\mathrm{n})$, mean $(\mu)$, additive genetic standard deviations $\left(\sigma_{\mathrm{g}}\right)$, heritability $\left(\mathrm{h}^{2} ; \mathrm{SE}\right.$ in parentheses), and repeatability ( $\mathrm{t}$; SE in parentheses) estimates for the detailed reproductive traits and calving performance

\begin{tabular}{lrcclc}
\hline Trait $^{1}$ & $\mathrm{n}$ & $\mu$ & $\sigma_{\mathrm{g}}$ & \multicolumn{1}{c}{$\mathrm{h}^{2}$} & $\mathrm{t}$ \\
\hline CYC & 47,209 & 0.87 & 0.09 & $0.07(0.010)^{* * *}$ & $0.67(0.010)^{* * *}$ \\
MO & 40,602 & 0.07 & 0.04 & $0.03(0.006)^{* * *}$ & $0.24(0.010)^{* * * *}$ \\
EO & 1,036 & 0.42 & 0.22 & $0.10(0.082)$ & \\
DH & 1,135 & 0.90 & 0.06 & $0.04(0.066)$ & $0.50(0.010)^{* * *}$ \\
CS & 27,803 & 0.03 & 0.01 & $0.002(0.003)$ & $0.24(0.010)^{* * *}$ \\
USC & 46,536 & 1.39 & 0.10 & $0.02(0.006)^{* * *}$ & $0.66(0.005)^{* * *}$ \\
EL & 40,465 & 0.08 & 0.04 & $0.02(0.006)^{*}$ & \\
Dystocia & 102,496 & 1.22 & $0.17^{2}$ & $0.21(0.015)^{2 * * *}$ & \\
Stillbirth & 102,745 & 0.06 & $0.05^{3}$ & $0.03(0.005)^{3 * * *}$ & \\
& & & $0.05^{2}$ & $0.06(0.009)^{2 * * *}$ & \\
\hline
\end{tabular}

${ }^{1} \mathrm{CYC}=$ resumption of cyclicity; $\mathrm{MO}=$ multiple ovulation; $\mathrm{EO}=$ early ovulation; $\mathrm{DH}=$ detected heat; $\mathrm{CS}=$ cystic structures; USC $=$ uterine score; EL = embryo loss.

${ }^{2}$ Direct component.

${ }^{3}$ Maternal component.

$* P<0.05 ;{ }^{* * *} P<0.001$ 


$$
\begin{aligned}
& X=\mu+\text { parity }+H Y S+H e t+R e c \\
& +\sum_{i=1}^{2} \text { Breed }_{i}+\text { animal }^{2} \text { pe }_{a}+e, \\
& Z=\mu+a g e+H Y S+H e t+R e c+\sum_{i=1}^{2} \text { Breed }_{i} \\
& + \text { animal }+e, \\
& U=\mu+H Y S+D I M+H e t+R e c+\sum_{i=1}^{2} \text { Breed }_{i} \\
& + \text { animal }+e,
\end{aligned}
$$

where $Y, X, Z$, and $U$ are the observed calving performance, milk production, carcass, and linear type traits, respectively; $\mu$ is the mean of trait; parity is the fixed effect of parity (i.e., 1, 2, 3, 4, or 5+); age is the fixed effect of age at slaughter; sex $x_{\text {calf }}$ is the fixed effect of the sex of the calf; $H Y S$ is the fixed effect of contemporary group; DIM is the fixed effect of a linear regression on days in milk at time of examination; Het is the fixed effect of the coefficient of heterosis of the animal; Rec is the fixed effect of the coefficient of recombination loss of the animal; $\sum_{i=1}^{2}$ Breed $_{i}$ is the proportion of each breed $_{i}\left(i=\right.$ Holstein and Friesian); Het $t_{d a m}$ is the fixed effect of the coefficient of heterosis of the dam; $\operatorname{Rec}_{d a m}$ is the fixed effect of the coefficient of recombination loss of the dam; animal is the random genetic effect of the animal; sire is the random genetic effect of the sire of the calf; $m g s$ is the random genetic effect of the maternal grand-sire sire of the calf; $p e_{a}$ is the random permanent environment effect across lactations; and $e$ is the random residual effect. The direct and maternal components for calving performance were assumed to be uncorrelated.

\section{RESULTS}

\section{Descriptive Statistics}

Summary statistics for the detailed reproductive traits and performance traits are in Tables 1 and 2, respectively. The mean percentage of cows that had resumed cyclicity at the time of ultrasound examination was $87 \%$; $42 \%$ had resumed cyclicity by $15 \mathrm{~d}$ postpartum. The mean prevalence of CS and EL in the data set was 3 and $8 \%$, respectively. Just over $71 \%$ of cows had a normal uterine environment (i.e., USC $=1$ ) at the time of examination, whereas $8.8 \%$ of cows exhibited poor uterine environments (i.e., USC >2). The percentage of calving difficulty scored as slight assistance, considerable assistance, and veterinary assistance were 24,5 , and $4 \%$, respectively. The prevalence of stillbirth in the data set was $6 \%$. Mean 305-d milk, fat, and protein yield was $6,878,271$, and $235 \mathrm{~kg}$, respectively. Mean fat-to-protein ratio was 1.16 with a phenotypic standard deviation (after adjusting for fixed effects) of 0.10. Average cow carcass weight was $300 \mathrm{~kg}$ and the average progeny carcass weight was $321 \mathrm{~kg}$. Cows had worse carcass conformation (2.80 units) and greater subcutaneous fat (6.45 units) compared with progeny carcass conformation (4.37 units) and fat (5.89 units).

\section{Variance Components}

Heritability estimates for the detailed reproductive traits (Table 1) have been described and discussed in detail elsewhere (Carthy et al., 2015); heritability ranged from 0.002 (CS) to 0.10 (EO). The heritability of direct and maternal calving performance traits was also low (0.01 to 0.21; Table 1 ); the direct heritability for both dystocia and perinatal mortality was greater than the corresponding maternal heritability. The heritability of milk production traits ranged from 0.25 to 0.29 for the yield traits and from 0.59 to 0.60 for the milk composition traits (Table 2); the heritability of SCS was 0.16. The coefficient of genetic variation of these traits varied from $4.7 \%$ (protein concentration) to $8.3 \%$ (fat concentration). The heritability of the carcass traits ranged from 0.16 to 0.25 for the cow carcass traits and from 0.22 to 0.28 for the progeny carcass traits (Table 2). The coefficient of genetic variation of the cow carcass traits varied from $5.8 \%$ (cow carcass weight) to $16.1 \%$ (cow carcass conformation) and the progeny carcass traits varied from $4.4 \%$ (progeny carcass weight) to $12.6 \%$ (progeny carcass conformation). The heritability of the body-related type traits ranged from 0.15 (BCS) to 0.45 (stature; Table 2). The coefficient of genetic variation for the body-related type traits ranged from $9.0 \%$ (body depth) to $16.7 \%$ (rump angle).

\section{Correlations Between Detailed Reproductive Traits and Calving Performance}

Increased direct dystocia (Table 3) was associated with a better uterine score and a greater likelihood of early ovulation (genetic correlation of -0.33 and 0.53 , respectively), whereas increased maternal dystocia was associated with a worse uterine score and a reduced likelihood of early ovulation (genetic correlation of 0.29 and -0.80 , respectively). The direct component of stillbirth was associated with a reduction in cyclicity and a poorer uterine environment (genetic correlation of -0.43 and 0.65 , respectively). The direct component of stillbirth was also associated with a better ability to detect heat (genetic correlation of 0.38). 
Table 2. Number of records $(\mathrm{n})$, mean $(\mu)$, additive genetic standard deviations $\left(\sigma_{\mathrm{g}}\right)$, heritability $\left(\mathrm{h}^{2}\right.$; SE in parentheses) and repeatability $(\mathrm{t}$; $\mathrm{SE}$ in parentheses) estimates for milk production, carcass traits, and linear type traits ${ }^{1}$

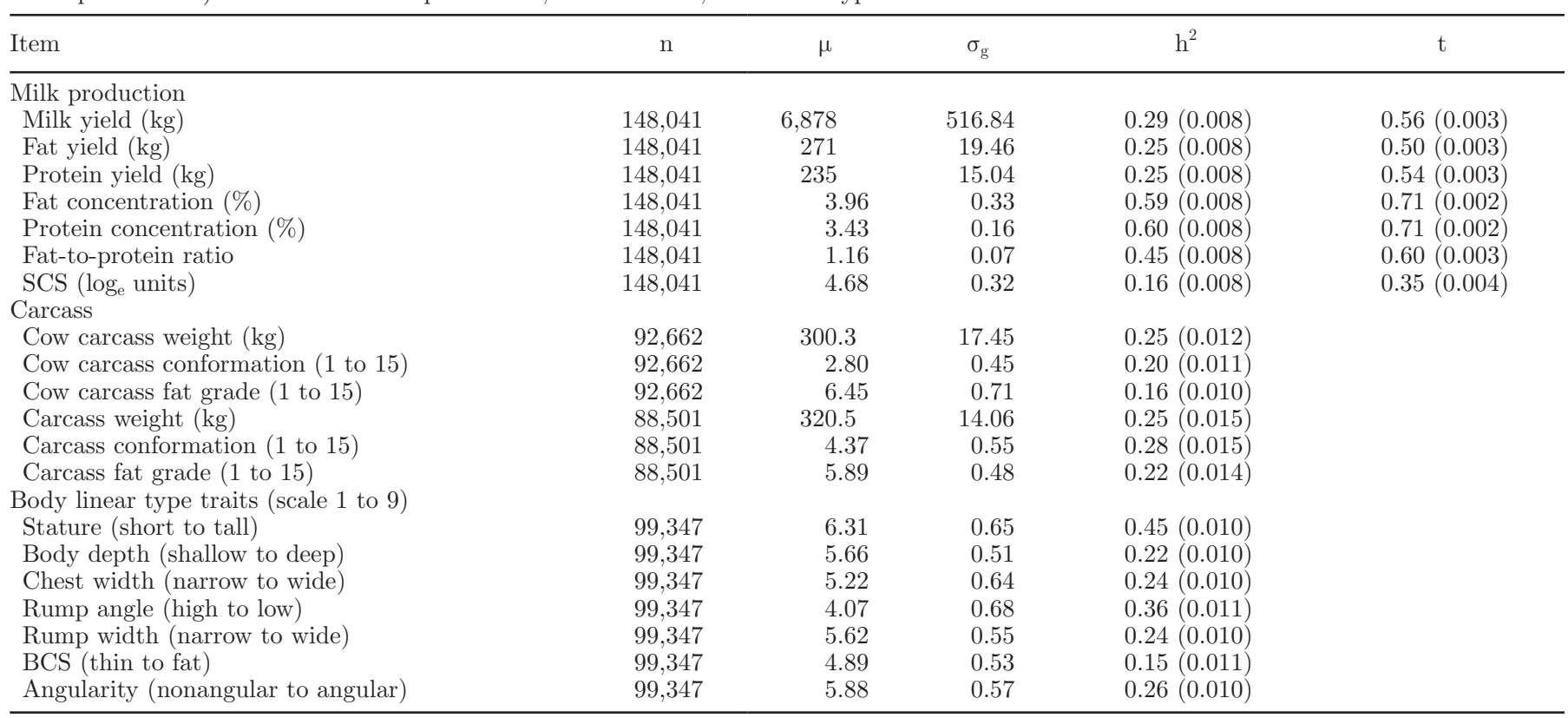

${ }^{1}$ All heritability and repeatability estimates were different $(P<0.001)$ from zero.

\section{Correlations Between Detailed Reproductive Traits and Milk Production}

Greater genetic merit for milk yield was associated with a reduction in CYC (genetic correlation of -0.25) and an increased likelihood of MO (genetic correlation of 0.18). Greater fat and protein yield were also associated with a reduced likelihood of CYC (genetic correlation of -0.22 and -0.15 , respectively). Greater protein concentration was genetically correlated with an increased likelihood of CYC (genetic correlation of 0.18 ) as well as a reduced likelihood of MO (genetic correlation of -0.21). Greater fat concentration was associated with a reduced genetic predisposition to EL (genetic correlation of -0.17 ). The genetic correlations between fat-to-protein ratio and most detailed reproductive traits were not different from zero except for the genetic correlation between fat-to-protein ratio and EL (Table 4).

Genetic predisposition for elevated (i.e., worse) SCS was associated with a reduced likelihood of CYC (genetic correlation of -0.32 ) and a greater likelihood of both MO (genetic correlation of 0.25 ) and EL (genetic correlation of 0.32 ).

\section{Correlations Between Detailed Reproductive Traits and Carcass Traits}

Genetically heavier cow carcasses were associated with an increased likelihood CYC at the time of ul-

Table 3. Genetic correlations (SE in parentheses) between detailed reproductive traits and calving performance ${ }^{1}$

\begin{tabular}{|c|c|c|c|c|}
\hline \multirow[b]{2}{*}{ Item } & \multicolumn{2}{|c|}{ Dystocia } & \multicolumn{2}{|c|}{ Stillbirth } \\
\hline & Direct & Maternal & Direct & Maternal \\
\hline $\mathrm{CYC}$ & $0.16(0.115)$ & $0.04(0.128)$ & $-0.43(0.127)^{* *}$ & $-0.19(0.167)$ \\
\hline MO & $-0.17(0.210)$ & $0.38(0.207)$ & $0.19(0.237)$ & $0.10(0.264)$ \\
\hline EO & $0.53(0.231)^{*}$ & $-0.80(0.240)^{* * *}$ & $-0.36(0.360)$ & $-0.05(0.381)$ \\
\hline $\mathrm{DH}$ & $0.16(0.185)$ & $-0.21(0.234)$ & $0.16(0.185) *$ & $-0.21(0.234)$ \\
\hline CS & $-0.15(0.164)$ & $0.10(0.172)$ & $0.38(0.187)$ & $0.19(0.213)$ \\
\hline USC & $-0.33(0.112)^{* *}$ & $0.29(0.123) *$ & $0.65(0.097)^{* * *}$ & $-0.06(0.155)$ \\
\hline $\mathrm{EL}$ & $0.17(0.407)$ & $0.59(0.401)$ & $0.23(0.410)$ & $0.44(0.416)$ \\
\hline
\end{tabular}

${ }^{1} \mathrm{CYC}=$ resumption of cyclicity; $\mathrm{MO}=$ multiple ovulation; $\mathrm{EO}=$ early ovulation; $\mathrm{DH}=$ detected heat; $\mathrm{CS}=$ cystic structures; USC $=$ uterine score; $\mathrm{EL}=$ embryo loss.

${ }^{*} P<0.05 ;{ }^{* *} P<0.01 ;{ }^{* * *} P<0.001$. 
Table 4. Genetic correlations (SE in parentheses) between the detailed reproductive traits and milk production ${ }^{1}$



${ }^{1} \mathrm{CYC}=$ resumption of cyclicity; $\mathrm{MO}=$ multiple ovulation; $\mathrm{EO}=$ early ovulation; $\mathrm{DH}=$ detected heat; $\mathrm{CS}=$ cystic structures; USC $=$ uterine score; EL = embryo loss.

$* P<0.05 ; * * P<0.01 ; * * * P<0.001$.

trasound examination (genetic correlation of 0.24 ), a greater number of multiple ovulations (genetic correlation of 0.20 ), and a poorer USC (genetic correlation of $0.22)$. Genetically fatter cows were also associated with an increased likelihood of CYC (genetic correlation of 0.41). Superior cow carcass conformation was associated with a greater likelihood of CYC (Table 5). Except for the genetic correlations between carcass fat grade and USC, the genetic correlations between the detailed reproductive traits and progeny carcass traits were not different from zero (Table 5).

\section{Correlations Between Detailed Reproductive Traits and Body-Related Type Traits}

The genetic correlation between BCS and CYC was moderately positive (0.52), indicating cows in better condition have, on average, a greater likelihood of hav- ing resumed cyclicity at the time of examination. Body condition score was not genetically associated with any other of the detailed reproductive traits (Table 6), although a tendency was found for better condition cows to resume cyclicity very early postpartum $(<15 \mathrm{~d})$ as well as having a greater likelihood of being detected in estrus (i.e., DH). Although weak, a significant association was also found between rump width and CYC. Genetically wider chests and less angular bodies were associated with a superior CYC (genetic correlations of 0.28 and -0.42 , respectively). Although associated with large standard errors, wider cows had a tendency to be genetically predisposed to EO (Table 6). The genetic correlations between body depth and EL indicated deeper bodies were predisposed to a greater likelihood of EL (Table 6). No associations were detected between the body-related type traits and CS, USC, or MO (Table 6).

Table 5. Genetic correlations (SE in parentheses) between the detailed reproductive traits and carcass traits ${ }^{1}$

\begin{tabular}{|c|c|c|c|c|c|c|c|}
\hline Item & CYC & MO & $\mathrm{EO}$ & $\mathrm{DH}$ & CS & USC & EL \\
\hline Cow carcass conformation & $\begin{array}{l}0.32 \\
(0.069) * * *\end{array}$ & $\begin{array}{c}0.16 \\
(0.103)\end{array}$ & $\begin{array}{c}-0.08 \\
(0.336)\end{array}$ & $\begin{array}{l}-0.36 \\
(0.193)\end{array}$ & $\begin{array}{c}-0.22 \\
(0.240)\end{array}$ & $\begin{array}{l}0.17 \\
(0.102)\end{array}$ & $\begin{array}{c}0.14 \\
(0.134)\end{array}$ \\
\hline Cow carcass fat grade & $\begin{array}{l}0.41 \\
(0.069) * * *\end{array}$ & $\begin{array}{l}0.06 \\
(0.108)\end{array}$ & $\begin{array}{l}0.13 \\
(0.331)\end{array}$ & $\begin{array}{c}-0.37 \\
(0.21)\end{array}$ & $\begin{array}{c}-0.53 \\
(0.354)\end{array}$ & $\begin{array}{l}0.30 \\
(0.101)\end{array}$ & $\begin{array}{c}0.12 \\
(0.139)\end{array}$ \\
\hline Carcass weight & $\begin{array}{l}0.06 \\
(0.088)\end{array}$ & $\begin{array}{c}0.12 \\
(0.121)\end{array}$ & $\begin{array}{l}0.36 \\
(0.322)\end{array}$ & $\begin{array}{l}-0.10 \\
(0.251)\end{array}$ & $\begin{array}{l}0.68 \\
(0.343)\end{array}$ & $\begin{array}{c}-0.11 \\
(0.116)\end{array}$ & $\begin{array}{c}0.07 \\
(0.156)\end{array}$ \\
\hline Carcass fat grade & $\begin{array}{l}0.11 \\
(0.089)\end{array}$ & $\begin{array}{l}0.08 \\
(0.119)\end{array}$ & $\begin{array}{c}-0.30 \\
(0.312)\end{array}$ & $\begin{array}{l}0.25 \\
(0.233)\end{array}$ & $\begin{array}{c}-0.20 \\
(0.268)\end{array}$ & $\begin{array}{l}0.29 \\
(0.110)^{*}\end{array}$ & $\begin{array}{c}0.30 \\
(0.137)\end{array}$ \\
\hline
\end{tabular}

${ }^{1} \mathrm{CYC}=$ resumption of cyclicity; $\mathrm{MO}=$ multiple ovulation; $\mathrm{EO}=$ early ovulation; $\mathrm{DH}=$ detected heat; $\mathrm{CS}=$ cystic structures; USC = uterine score; EL = embryo loss.

${ }^{*} P<0.05 ;{ }^{* *} P<0.01 ;{ }^{* * *} P<0.001$. 
Table 6. Genetic correlations (SE in parentheses) between the detailed reproductive traits and linear type traits ${ }^{1}$

\begin{tabular}{|c|c|c|c|c|c|c|c|}
\hline Item & CYC & MO & EO & $\mathrm{DH}$ & CS & USC & EL \\
\hline Body depth & $\begin{array}{c}0.01 \\
(0.069)\end{array}$ & $\begin{array}{c}0.07 \\
(0.098)\end{array}$ & $\begin{array}{l}0.49 \\
(0.265)\end{array}$ & $\begin{array}{c}-0.01 \\
(0.195)\end{array}$ & $\begin{array}{l}0.25 \\
(0.216)\end{array}$ & $\begin{array}{c}0.05 \\
(0.097)\end{array}$ & $\begin{array}{l}0.31 \\
(0.140)^{*}\end{array}$ \\
\hline Chest width & $\begin{array}{l}0.28 \\
(0.067)^{* * *}\end{array}$ & $\begin{array}{c}-0.06 \\
(0.096)\end{array}$ & $\begin{array}{l}0.63 \\
(0.306)^{*}\end{array}$ & $\begin{array}{c}0.19 \\
(0.192)\end{array}$ & $\begin{array}{l}0.17 \\
(0.212)\end{array}$ & $\begin{array}{c}0.06 \\
(0.096)\end{array}$ & $\begin{array}{c}-0.05 \\
(0.130)\end{array}$ \\
\hline Rump angle & $\begin{array}{c}0.07 \\
(0.063)\end{array}$ & $\begin{array}{c}-0.15 \\
(0.094)\end{array}$ & $\begin{array}{c}0.16 \\
(0.225)\end{array}$ & $\begin{array}{c}-0.21 \\
(0.177)\end{array}$ & $\begin{array}{l}0.16 \\
(0.230)\end{array}$ & $\begin{array}{c}0.02 \\
(0.092)\end{array}$ & $\begin{array}{c}-0.14 \\
(0.129)\end{array}$ \\
\hline $\mathrm{BCS}$ & $\begin{array}{l}0.52 \\
(0.073)^{* * *}\end{array}$ & $\begin{array}{c}-0.04 \\
(0.114)\end{array}$ & $\begin{array}{c}0.56 \\
(0.317)\end{array}$ & $\begin{array}{c}0.29 \\
(0.222)\end{array}$ & $\begin{array}{l}0.15 \\
(0.243)\end{array}$ & $\begin{array}{c}0.07 \\
(0.115)\end{array}$ & $\begin{array}{c}-0.05 \\
(0.154)\end{array}$ \\
\hline Angularity & $\begin{array}{l}-0.42 \\
(0.064) * * *\end{array}$ & $\begin{array}{c}0.07 \\
(0.096)\end{array}$ & $\begin{array}{c}-0.10 \\
(0.249)\end{array}$ & $\begin{array}{c}-0.24 \\
(0.197)\end{array}$ & $\begin{array}{c}-0.01 \\
(0.207)\end{array}$ & $\begin{array}{c}-0.01 \\
(0.096)\end{array}$ & $\begin{array}{l}0.04 \\
(0.072)\end{array}$ \\
\hline
\end{tabular}

${ }^{1} \mathrm{CYC}=$ resumption of cyclicity; $\mathrm{MO}=$ multiple ovulation; $\mathrm{EO}=$ early ovulation; $\mathrm{DH}=$ detected heat; $\mathrm{CS}=$ cystic structures; USC $=$ uterine score; EL = embryo loss.

${ }^{*} P<0.05 ;{ }^{* *} P<0.01 ;{ }^{* * *} P<0.001$.

\section{DISCUSSION}

Since the inclusion of reproductive traits in breeding objectives to achieve a more balanced, holistic breeding objective, the decline in reproductive performance has halted and in many populations improved (Berry et al., 2014). The association between the commonly used traits for reproductive performance, calving interval and days open, and the detailed aspects of reproductive performance are, however, not unity (Carthy et al., 2015), suggesting a possible difference in the underlying genetic control of these reproductive traits. Therefore, to determine the effect of current breeding strategies on underlying reproductive performance, the genetic relationships between detailed reproductive traits and performance traits included in breeding goals must first be established. Thus, the objective of the present study was to estimate the associations between detailed reproductive traits, collected during routine ultrasound examinations of the reproductive tract, and both performance and functional traits included in many dairy cow breeding goals.

\section{Variance Components}

Variance components for the detailed reproductive traits are discussed in detail elsewhere (Fitzgerald et al., 2014b; Carthy et al., 2015). In brief, the detailed reproductive traits were lowly heritable $(<0.10)$, although considerable genetic variation was detected as evidenced by the genetic standard deviation of the binary traits ranging from 0.01 to 0.22 . The greatest heritability and genetic variation was observed for traits related to cyclicity $(\mathrm{CYC}, \mathrm{EO}$, and $\mathrm{DH})$. Heritability estimates for the calving performance traits, with the expectation of direct dystocia, were also low $(<0.06)$. The direct component of the calving performance traits was more heritable than the respective maternal component, corroborating heritability estimates from UK (Eaglen et al., 2013) and Dutch (Eaglen and Bijma, 2009) dairy populations. Milk production, carcass traits, and body type traits exhibited considerably greater heritability estimates than the reproductive and calving performance traits, but nonetheless were consistent with reported heritability estimates in other international populations (Hoekstra et al., 1994; Pryce et al., 2000; Berry and Evans, 2014).

\section{Reproductive Traits and Calving Performance}

The maternal component of a difficult calving was associated with a reduced likelihood of ovulating early postpartum; however, no association was detected between maternal calving difficulty and cyclicity, indicating a difficult calving may result in a poorer ability to resume cyclicity early postpartum but not affect overall cyclicity. The genetic correlations between direct calving difficult and early ovulation indicate that a calf born through difficult calving is genetically predisposed to earlier ovulation postpartum once the heifer calf becomes a cow. The results obtained in the present study are consistent with those documented by Eaglen et al. (2013) who reported a greater genetic predisposition to maternal calving difficulty was associated with a longer calving interval whereas direct calving difficulty was associated with superior nonreturn rates. In the present study, the association between genetic predisposition to stillbirth and cyclicity suggests that sires with a greater incidence of stillbirth will also produce daughters less likely to resume cyclicity postcalving. 


\section{Reproductive Traits and Milk Production}

The antagonistic genetic correlations in the present study between the detailed reproductive traits and milk production corroborate the now generally accepted antagonistic genetic relationship (Berry et al., 2104), indicating that the documented genetic antagonisms with milk production affect several different aspects of reproductive performance, although the strength of the relationship varies with the different detailed aspect of reproductive performance.

In particular, the observed antagonistic genetic correlation between milk production and CYC in the present study corroborates the previously documented genetic correlations with other cyclicity traits, measured both traditionally (calving to first service; Kadarmideen et al., 2000; Veerkamp et al., 2001) or from hormonal profiles (commencement to luteal activity; Pryce et al., 2000; Veerkamp et al., 2000; Royal et al., 2002a). From a subset of the data set used in the present study, Fitzgerald et al. (2014b) documented that cows with the highest predicted transmitting ability for milk production were $50 \%$ less likely to have resumed cyclicity at the time of ultrasound examination compared with their lower predicted transmitting ability contemporaries. Moreover, based on the genetic parameters estimated in the present study, a $100-\mathrm{kg}$ greater genetic merit in 305-d milk yield is, on average, expected to result in a 0.4 percentage unit reduction in $\mathrm{CYC}$, whereas a 10-kg increase in milk fat and protein yield is expected to translate into a 1.0 and 1.5 percentage unit reduction in CYC, respectively. In some production systems, synchronization programs are advocated as an approach to mitigate the effect of selection for milk production on the likelihood of a cow cycling early postpartum. However, the heritable genetic variation for CYC observed in the present study and elsewhere (Berry et al., 2014) for postpartum return to cyclicityassociated traits suggests that such approaches may only serve to perpetuate the issue of anestrus especially if heifer replacements are retained from such cows. Herlihy et al. (2011) reported that despite the increase in submission rate observed in dairy cows subjected to synchronization programs, no difference was observed in pregnancy rate between synchronized and nonsynchronized cows; this therefore suggests that hormonal intervention is not a suitable long-term alternative to a breeding program to negate the effect of selection for milk production on overall reproductive performance.

Many dairy cow breeding goals now include traditional (generally producer generated) measures of reproductive performance as a means to slow down, halt, or reverse unfavorable genetic trends in all aspects of reproductive performance. No genetic correlation ex- isted between milk yield and CYC in the present study after adjusting for genetic differences in calving interval, assuming a genetic correlation of 0.46 (Berry et al., 2014). Selection on calving interval in national dairy breeding programs may, therefore, overcome the unfavorable association that exists between milk production and CYC; whether that is achieved will be dependent on the relative emphasis on both milk production and calving interval and also on the other traits included in the breeding goal. For example, selection for milk production traits, assuming the current economic values in the Irish national breeding goal ( $-€ 0.09, € 1.04$, and $€ 6.64$ for milk, fat, and protein yield, respectively), and calving interval ( $-€ 12.43)$, would result in a 5-percentage-unit increase in CYC per genetic standard deviation improvement in the index. This, however, was achievable due to the high relative emphasis $(64 \%)$ on calving interval within this index because of the importance of reproductive performance in seasonal calving production systems as exist in Ireland (Berry et al., 2013). If, however, calving interval was not included in the index, $7 \%$ emphasis on cyclicity is required to prevent any deterioration in cyclicity.

Contrary to previously documented genetic correlations between milk production with both cystic structures and uterine infection, no such association was detected in the present study. An unfavorable genetic association has been previously documented between CS and milk production (Hooijer et al., 2001; Koeck et al., 2012). However, methods of detection of cystic structures vary between studies, and this could contribute to the inconsistency in results among studies. Furthermore, the lower prevalence of CS in the population used in the present study may also be contributing to the differences among studies. Likewise, the present study did not directly measure uterine infection, but rather evaluated the tone and fluid present within the uterus. The previously documented unfavorable genetic association between milk production and uterine infection has been estimated from diagnosed metritis events (Pösö and Mäntysaari, 1996), which are a more reliable measure of uterine infection than that used in the present study.

Energy balance postpartum has been documented to be an important factor determining reproductive success (Butler and Smith, 1989). Body fatness in particular is mobilized in periods of negative energy balance to maintain milk production (Roche et al., 2009). Milk fat concentration tends to increase, whereas milk protein concentration tends to decrease in periods of negative energy balance (Grieve et al., 1985); for this reason, fat-to-protein ratio has often been cited as a potential indicator of energy balance and the health status of the cow (Heuer et al., 1999). Nonetheless, phenotypic corre- 
lations between fat-to-protein ratio and other measures of energy balance have been shown to be close to zero (McParland et al., 2011). No genetic associations were detected in the present study between fat-to-protein ratio and the detailed reproductive traits, further corroborating the results documented by Fitzgerald et al. (2014b) who failed to detect any differences in detailed reproductive traits among cows who were low, average, or high genetic merit in fat-to-protein ratio. The results of the present study, in conjunction with those of Fitzgerald et al. (2014b) and elsewhere (McParland et al., 2011), therefore suggest that the benefit of using fat-to-protein ratio as an indicator of detailed reproductive performance at an individual cow level is questionable.

Greater SCS is an indication of, among others, a response to mastitis infection (Harmon, 1994). Cows with greater genetic predisposition to elevated SCS may allocate more energy to combat infection at the expense of other bodily function such as reproductive performance. Cows that are genetically predisposed to greater SCS not only had an inferior genetic merit for CYC in the present study but also had a greater likelihood of EL, both of which could be contributing to documented antagonistic genetic correlations that exist between SCS and traditional reproductive traits, such as calving interval (Haile-Mariam et al., 2003).

\section{Reproductive Traits and Body Fatness, Size, and Shape}

Body condition score is a subjective measurement of body fat used to determine body reserves and is well known to be associated with reproductive performance (Roche et al., 2009). Dairy cows with genetically better BCS have also been documented to, on average, have superior genetic merit for traditional reproductive traits (Pryce et al., 2000; Berry et al., 2003) and commencement of luteal activity (Royal et al., 2002b). Likewise, (subcutaneous) carcass fat, a trait similar to BCS, has been previously reported to genetically associated with a shorter calving interval in beef cows (Berry and Evans, 2014). These previously documented favorable associations between the ability to resume cyclicity and body fatness were further supported in the present study, irrespective of whether the fatness phenotype was BCS or carcass subcutaneous fat. However, genetically greater subcutaneous carcass fat was also associated with a poorer uterine environment, although no association was detected between BCS and the uterine environment in the present study. Using the (co)variance components estimated in the present study, a 1 unit increase in genetic merit in BCS (scale 1 to 9 ), would result, on average, in a 7 percentage unit improvement in the ability to resume cyclicity. The genetic correlations that existed between BCS and the detailed reproductive traits were generally consistent with those estimated with angularity, which is genetically very similar, yet opposite in scale, to BCS (Berry et al., 2004).

A paucity of studies have quantified the genetic associations between carcass traits and reproductive performance, particularly in dairy cows. However, genetic correlations between live weight and reproductive performance suggest that greater live weight is associated with a shorter interval to both first service (Berry et al., 2003) and luteal activity (Veerkamp et al., 2000). The genetic correlation between carcass weight and CYC in the present study is consistent with those reported from other populations between live weight and cyclicity related traits (Veerkamp et al., 2000), suggesting that genetically heavier animals resume cyclicity earlier. However, when carcass weight was adjusted for difference in genetic merit for BCS, the genetic correlation between carcass weight and cyclicity was not different to zero. Thus, the favorable association that exists between carcass weight and cyclicity could be almost entirely explained by the greater energy reserve available in heavier cows. The existence of phenotypic (Berry et al., 2011b) and genetic (Berry et al., 2003) associations between BCS and live weight is well known. Despite the genetic association between heavier animal weight and earlier postpartum return to estrus, genetically heavier animals have, on average, poorer pregnancy rates and a longer interval to conception (Berry et al., 2003). Similarly, genetically heavier beef cows are expected to have longer inter-calving intervals (Berry and Evans, 2014). Coupled with the genetic correlations in the present study between carcass weight and USC, these results altogether suggest genetically heavier animals have a compromised ability to conceive.

The observed genetic correlations in the present study between CYC and the remainder of the bodyrelated traits were generally consistent with previously documented correlations between body-related traits and both calving interval (Pryce et al., 2000; Dal Zotto et al., 2007) and calving to first service interval (Berry et al., 2004); genetically smaller, wider, less angular cows had a greater likelihood of having resumed cyclicity by the time of ultrasound examination. The angle of the rump has been suggested to be associated with an increased risk of uterine infection postpartum (Wall et al., 2005). The upward angle of the vaginal canal in cows with high pins has been suggested to cause difficulty in expelling uterine fluid postpartum, leading to prolonged infection (Wall et al., 2005). No evidence was found, however, in the present study of an association between rump angle and USC. Furthermore, if an as- 
sociation exists between rump angle and uterine infection, rump angle would be expected to be also associated with other measures of reproductive performance, such calving interval and calving to first service, which is not widely documented (Pryce et al., 2000; Dal Zotto et al., 2007).

\section{CONCLUSIONS}

The results of the present study suggest that, despite the known antagonistic genetic relationship between milk production traits and traditional reproduction performance, not all detailed aspects of reproductive performance exhibited an unfavorable relationship. After accounting for BCS, the initial favorable relationship between carcass weight and the ability to resume cyclicity no longer existed. The antagonistic genetic relationship that existed between the carcass traits and traditional reproduction performance could be underpinned by the unfavorable genetic relationship between carcass traits and both the uterine environment and embryo loss.

\section{ACKNOWLEDGMENTS}

Funding from the Irish Department of Agriculture, Food and Marine Research Stimulus Fund (RSF 11/S/133), Dublin, Ireland, and the OptiMIR (http:// www.optiMIR.eu/) project is gratefully acknowledged.

\section{REFERENCES}

Berry, D. P., J. Bastiaansen, R. Veerkamp, S. Wijga, E. Wall, B. Berglund, and M. Calus. 2012. Genome-wide associations for fertility traits in Holstein-Friesian dairy cows using data from experimental research herds in four European countries. Animal 6:1206-1215.

Berry, D. P., F. Buckley, P. Dillon, R. Evans, and R. Veerkamp. 2004. Genetic relationships among linear type traits, milk yield, body weight, fertility and somatic cell count in primiparous dairy cows. Ir. J. Agric. Food Res. 43:161-176.

Berry, D., J. Kearney, K. Twomey, and R. Evans. 2013. Genetics of reproductive performance in seasonal calving dairy cattle production systems. Ir. J. Agric. Food Res. 52:1-16.

Berry, D. P., M. L. Bermingham, M. Good, and S. J. More. 2011a. Genetics of animal health and disease in cattle. Ir. Vet. J. 64:5.

Berry, D. P., F. Buckley, and P. Dillon. 2011b. Relationship between live weight and body condition score in Irish Holstein-Friesian dairy cows. Ir. J. Agric. Food Res. 50:141-147.

Berry, D. P., F. Buckley, P. Dillon, R. D. Evans, M. Rath, and R. F. Veerkamp. 2003. Genetic relationships among body condition score, body weight, milk yield, and fertility in dairy cows. J. Dairy Sci. 86:2193-2204.

Berry, D. P., and R. D. Evans. 2014. Genetics of reproductive performance in seasonal calving beef cows and its association with performance traits. J. Anim. Sci. 92:1412-1422.

Berry, D. P., E. Wall, and J. E. Pryce. 2014. Genetics and genomics of reproductive performance in dairy and beef cattle. Animal $8: 105-121$.

Butler, W. R., and R. D. Smith. 1989. Interrelationships between energy balance and postpartum reproductive function in dairy cattle. J. Dairy Sci. 72:767-783.
Carthy, T. R., D. P. Berry, A. Fitzgerald, S. McParland, E. J. Williams, S. T. Butler, A. R. Cromie, and D. Ryan. 2014. Risk factors associated with detailed reproductive phenotypes in dairy and beef cows. Animal 8:695-703.

Carthy, T. R., D. Ryan, A. Fitzgerald, R. D. Evans, and D. P. Berry. 2015. Genetic parameters of ovarian and uterine reproductive traits in dairy cows. J. Dairy Sci. 98:4095-4106.

Dal Zotto, R., M. De Marchi, C. Dalvit, M. Cassandro, L. Gallo, P. Carnier, and G. Bittante. 2007. Heritabilities and genetic correlations of body condition score and calving interval with yield, somatic cell score, and linear type traits in Brown Swiss cattle. J. Dairy Sci. 90:5737-5743.

Eaglen, S. A. E., and P. Bijma. 2009. Genetic parameters of direct and maternal effects for calving ease in Dutch Holstein-Friesian cattle. J. Dairy Sci. 92:2229-2237.

Eaglen, S. A. E., M. P. Coffey, J. A. Woolliams, and E. Wall. 2013. Direct and maternal genetic relationships between calving ease, gestation length, milk production, fertility, type, and lifespan of Holstein-Friesian primiparous cows. J. Dairy Sci. 96:4015-4025.

Fitzgerald, A. M., D. Berry, T. Carthy, A. Cromie, and D. Ryan. 2014a. Risk factors associated with multiple ovulation and twin birth rate in Irish dairy and beef cattle. J. Anim. Sci. 92:966-973

Fitzgerald, A. M., D. P. Ryan, T. R. Carthy, R. D. Evans, and D. P. Berry. 2014b. Ovarian structures and uterine environment are associated with phenotypic and genetic merit for performance in lactating dairy cows. Theriogenology 82:1231-1240.

Gilmour, A., B. Cullis, S. Welham, and R. Thompson. 2009. ASREML Reference Manual. New South Wales Agriculture, Orange Agricultural Institute, Orange, NSW, Australia.

Grieve, D. G., S. Korver, Y. S. Rijpkema, and G. Hof. 1985. Relationship between milk composition and some nutritional parameters in early lactation. Livest. Prod. Sci. 14:239-254.

Haile-Mariam, M., P. J. Bowman, and M. E. Goddard. 2003. Genetic and environmental relationship among calving interval, survival, persistency of milk yield and somatic cell count in dairy cattle. Livest. Prod. Sci. 80:189-200.

Harmon, R. J. 1994. Physiology of mastitis and factors affecting somatic cell counts. J. Dairy Sci. 77:2103-2112.

Herlihy, M. M., D. P. Berry, M. A. Crowe, M. G. Diskin, and S. T. Butler. 2011. Evaluation of protocols to synchronize estrus and ovulation in seasonal calving pasture-based dairy production systems. J. Dairy Sci. 94:4488-4501.

Heuer, C., Y. Schukken, and P. Dobbelaar. 1999. Postpartum body condition score and results from the first test day milk as predictors of disease, fertility, yield, and culling in commercial dairy herds. J. Dairy Sci. 82:295-304.

Hickey, J. M., M. G. Keane, D. A. Kenny, A. R. Cromie, and R. F. Veerkamp. 2007. Genetic parameters for EUROP carcass traits within different groups of cattle in Ireland. J. Anim. Sci. 85:314321.

Hoekstra, J., A. Van der Lugt, J. Van der Werf, and W. Ouweltjes. 1994. Genetic and phenotypic parameters for milk production and fertility traits in upgraded dairy cattle. Livest. Prod. Sci. 40:225232.

Hooijer, G. A., R. B. F. Lubbers, B. J. Ducro, J. A. M. van Arendonk, L. M. T. E. Kaal-Lansbergen, and T. van der Lende. 2001. Genetic parameters for cystic ovarian disease in Dutch Black and White dairy cattle. J. Dairy Sci. 84:286-291.

Kadarmideen, H., R. Thompson, and G. Simm. 2000. Linear and threshold model genetic parameters for disease, fertility and milk production in dairy cattle. Pages $83-84$ in Br. Soc. Anim. Sci. Occas. Publ. Br. Soc. Anim. Sci., Penicuik, UK.

Koeck, A., F. Miglior, D. F. Kelton, and F. S. Schenkel. 2012. Health recording in Canadian Holsteins: Data and genetic parameters. J. Dairy Sci. 95:4099-4108.

McParland, S., G. Banos, E. Wall, M. P. Coffey, H. Soyeurt, R. F. Veerkamp, and D. P. Berry. 2011. The use of mid-infrared spectrometry to predict body energy status of Holstein cows. J. Dairy Sci. 94:3651-3661.

Miglior, F., B. Muir, and B. Van Doormaal. 2005. Selection indices in Holstein cattle of various countries. J. Dairy Sci. 88:1255-1263. 
Norman, H. D., J. R. Wright, M. T. Kuhn, S. M. Hubbard, J. B. Cole, and P. M. VanRaden. 2009. Genetic and environmental factors that affect gestation length in dairy cattle. J. Dairy Sci. 92:2259 2269 .

Pösö, J., and E. A. Mäntysaari. 1996. Genetic relationships between reproductive disorders, operational days open and milk yield. Livest. Prod. Sci. 46:41-48.

Pryce, J. E., M. Coffey, and S. Brotherstone. 2000. The genetic relationship between calving interval, body condition score and linear type and management traits in registered Holsteins. J. Dairy Sci. $83: 2664-2671$.

Roche, J. R., N. C. Friggens, J. K. Kay, M. W. Fisher, K. J. Stafford, and D. P. Berry. 2009. Invited review: Body condition score and its association with dairy cow productivity, health, and welfare. J. Dairy Sci. 92:5769-5801.

Royal, M. D., A. P. F. Flint, and J. A. Woolliams. 2002a. Genetic and phenotypic relationships among endocrine and traditional fertility traits and production traits in Holstein-Friesian dairy cows. J. Dairy Sci. 85:958-967.

Roval, M. D., J. Pryce, J. Woolliams, and A. Flint. 2002b. The genetic relationship between commencement of luteal activity and calving interval, body condition score, production, and linear type traits in Holstein-Friesian dairy cattle. J. Dairy Sci. 85:3071-3080.
VanRaden, P. M., and A. H. Sanders. 2003. Economic merit of crossbred and purebred US dairy cattle. J. Dairy Sci. 86:1036-1044.

Veerkamp, R. F., E. Koenen, and G. De Jong. 2001. Genetic correlations among body condition score, yield, and fertility in firstparity cows estimated by random regression models. J. Dairy Sci. 84:2327-2335.

Veerkamp, R. F., J. Oldenbroek, H. Van Der Gaast, and J. Van Der Werf. 2000. Genetic correlation between days until start of luteal activity and milk yield, energy balance, and live weights. J. Dairy Sci. 83:577-583.

Veerkamp, R. F., and B. Beerda. 2007. Genetics and genomics to improve fertility in high producing dairy cows. Theriogenology 68(Suppl. 1):S266-S273.

Wall, E., I. M. S. White, M. P. Coffey, and S. Brotherstone. 2005. The relationship between fertility, rump angle, and selected type information in Holstein-Friesian cows. J. Dairy Sci. 88:1521-1528.

Zwald, N. R., K. A. Weigel, Y. M. Chang, R. D. Welper, and J. S. Clay. 2004. Genetic selection for health traits using producerrecorded data. II. Genetic correlations, disease probabilities, and relationships with existing traits. J. Dairy Sci. 87:4295-4302. 